\title{
Review on Striga Distribution, Infestation and Genetic Potential in Ethiopian Sorghum (Sorghum Bicolor (L.) Moench)
}

\author{
Temesgen Teressa \\ Ethiopian Institute of Agricultural Research, Melkassa Agricultural Research Center, P.O Box 346 Adama, \\ Ethiopia \\ *Corresponding Author: Temesgen Teressa, Ethiopian Institute of Agricultural Research, Melkassa \\ Agricultural Research Center, P.O Box 346 Adama, Ethiopia
}

\begin{abstract}
Witch weeds (Striga spp.), endemic parasitic weeds of sub-Saharan Africa including Ethiopia are steadily increasing their geographic domain and level of infestation, and thereby greatly reducing crop yield. They have become a widely acknowledged scourge. The Striga problem undermines the struggle to attain food security and economic growth. Countries with nascent infestation of Striga only 25 years ago are now showing heavy annual losses of crop yield. Annual sorghum loss attributed to striga in SSA is estimated to 22$27 \%$ and $25 \%$ in Ethiopia. The annual loss of all cereals due to striga is \$7 billion in SSA and the share of Ethiopia is \$75 million. In Ethiopia striga is major biotic constraint and serious threat of subsistence food production. Striga hermonthica is the dominant species it is most sever in highly degraded areas of North, North Western and Eastern parts of the country such as Tigray, Wollo, Gonder, Gojjem, North Shewa and Eastern Harerghe. Striga is, therefore, fast becoming a pandemic of serious proportions in the country because of its vast geographic spread and its economic impact on millions. Ethiopia is the source of diverse sorghum germplasm and there is the opportunity to develop striga resistance varieties.
\end{abstract}

Keywords: Sorghum, Striga, Varieties, Resistance

Acronyms and Abbreviations: ISM=Integrated Striga Management, SSA=Sub-Saharan Africa, ICRISAT=International Crops Research Institute for the Semi-Arid Tropics, EARO=Ethiopian Agricultural Research Organization

\section{INTRODUCTION}

Witch weeds (Strigaspp.), endemic parasitic weeds of sub-Saharan Africa are steadily increasing their geographic domain and level of infestation, and thereby greatly reducing crop yield. It is one of the major biotic factors constraining sorghum [(Sorghum bicolor (L.) Moench)] production in several tropical and subtropical regions of sub-Saharan Africa including Ethiopia. The parasite also attacks other crops including rice, millet, and maize (Rich et al, 2004, Ejeta, 2007). Badu-Apraku and Akin wale (2011) reported that Striga could cause yield losses ranging from 20 to 80\%. Infestation by Striga could result in yield loss of few percentages and in some cases complete crop failure (Gurney et al., 2002; Rodenburg et al., 2005). Yield loss ranging between 65 and 100\% has been reported in sorghum in Ethiopia and Sudan (Ejeta et al., 2002).

The use of resistant genotypes is considered the most cost effective and efficient control option in combating Striga (Haussmann et al., 2000; Ejeta and Gressel, 2007). However, the search for good sources to Striga are major challenges in Striga resistance breeding and finding an effective and sustainable means of controlling Striga in sorghum.

The annual yield loss due to Striga alone was estimated at US \$7 billion in sub-Saharan Africa, posing a major threat to the livelihood of over 100 million people (Badu-Apraku and Akin wale, 2011).

\subsection{Statement of the Problem}

Striga is a severe problem in the cereal growing regions of northern and Eastern Ethiopia (Fasil et al., 2010).Surveys in the north eastern and western parts of Ethiopia showed that Striga has remained a serious problem, attacking finger millet, sorghum and maize (Rebka et al., 2014). 


\subsubsection{General Objective}

To review the distribution and infestation of Striga in Ethiopia

\subsubsection{Specific Objectives}

To assess areas of distribution of striga in Ethiopia

To review on the infestation level and potential in Ethiopia

\section{LitratURE REVIEW}

\subsection{Constraints of Sorghum Productions}

The livelihoods of millions of subsistence farmers depend on sorghum production in Ethiopia. However, its productivity is low at around 2 tons per hectare (Legesse, 2015). This is attributed to a number of a biotic and biotic stresses. Yield reducing factors include Striga, low soil fertility (nutrient deficiency), drought, stem borers, and shoot fly (Wortmann et al., 2006). Although these constraints cause a significant loss of grain, the level of losses varies from region to region. In Ethiopia, Striga is a major production constraint in most sorghum producing areas. The weed limits the productivity of the crop by allelopathy, competition for nutrients and limiting the expression of the full genetic potential of sorghum plants.

Wortmann et al. (2006) and Dugje et al. (2006) reported that the paramount yield reducing factors in sorghum in eastern Africa, including Ethiopia are Striga and low soil fertility (nutrient deficiency). Consequently, the current research conducted in the north western parts of Ethiopia, which represents one of the Ethiopia's sorghum growing belt indicated that, Striga is the number one constraint in sorghum followed by low soil fertility and drought.

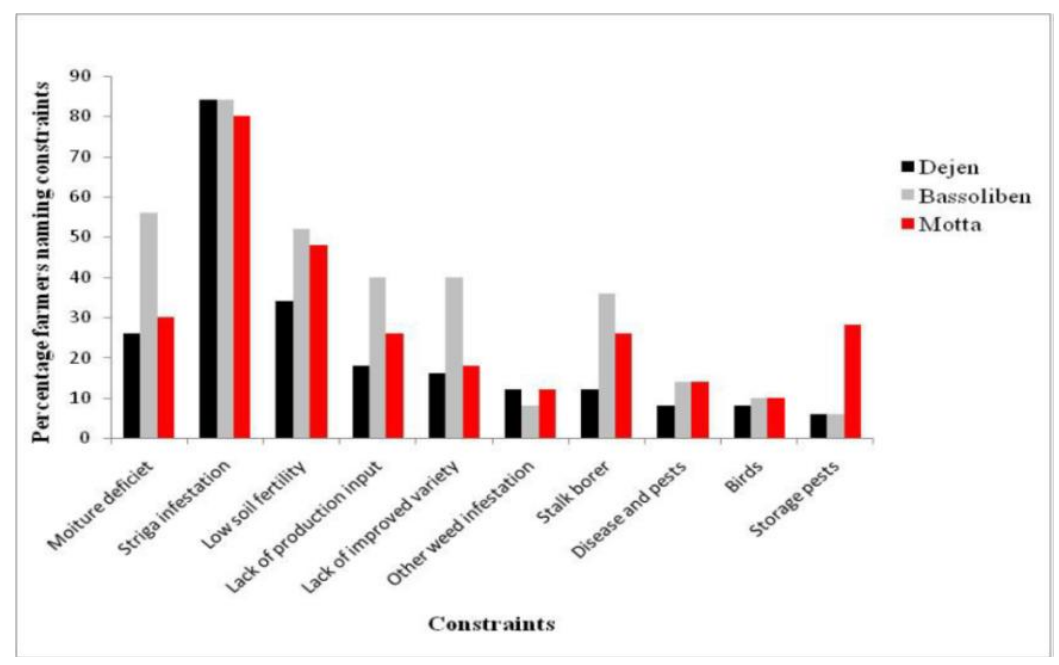

Figure1. Major Sorghum production constraints described by farmers Dejen, Bessoliban and Motta

Source: Mesfin A.2016

\subsection{Striga(Striga spp)}

The genus Striga belongs to the family Orobanchaceae (formerly: Scrophulariaceae). This genus parasitizes cereal crops such as rice (Oryza glaberrima Steudel and O. sativa L.), pearl millet (Pennisetum glaucum L. R. Br. or P. americanum [L.] K. Schum), maize (Zea mays L.), and sorghum [(Sorghum bicolor (L.)Moench)] (Parker, 1991; Johnson et al., 1997). It also parasitizes many wild grass species in Africa. There are more than 50 species of Striga, with several species affecting the production of cereals and legumes in sub-Saharan Africa and Asia (Parker and Riches, 1993; Kiruki et al., 2006).

The Striga species are among the most specialized of all root-parasitic plant parasites (Parker and Riches, 1993). Striga combines the life styles of both a holo-parasite at the seedling stage and a hemi parasite as a green, chlorophyll-containing emergent plant (Mohamed et al., 2001). Of the parasitic species of Striga, S. hermonthica, S. asiatica, S. aspera, S. forbesii and S. gesnerioidesare of particular economic importance as crop parasites in Africa (Mohamed et al., 2001). 
These species attack all the important tropical cereals except S. gesnerioides which parasitizes only dicotyledons.

Striga hermonthica (Del.) Benth (Scrophulariacae) is one of the major production constraints to sorghum, millet, rice and maize production in the dry land zones of Africa (Rao and Mussel man, 1987; Gebisa, 2007). It is also a problem in the subsistence agriculture regions of Ethiopia. The problem in those areas is aggravated by the inherent low soil fertility, recurrent drought and overall natural resource degradation because of decades of continuous cereal monoculture and deforestation. The spread of striga has increased with a consequent decrease in food production in many countries (Fasil, 2002). The losses attributed to striga weed range between 30 and 100 percent in most areas (Gebisa, 2007), and are often exacerbated by low soil fertility. In traditional African cropping, prolonged fallow, crop rotation and intercropping were the common practices that kept Striga infestation in tolerable level. This parasitic weed cause estimated yield losses that range from 40 to $100 \%$ when the infestation is very serious, especially in northern, north western and eastern parts of the country where sorghum cropping is the most suitable choice for farmers (Kidane, 2014) (Figure).

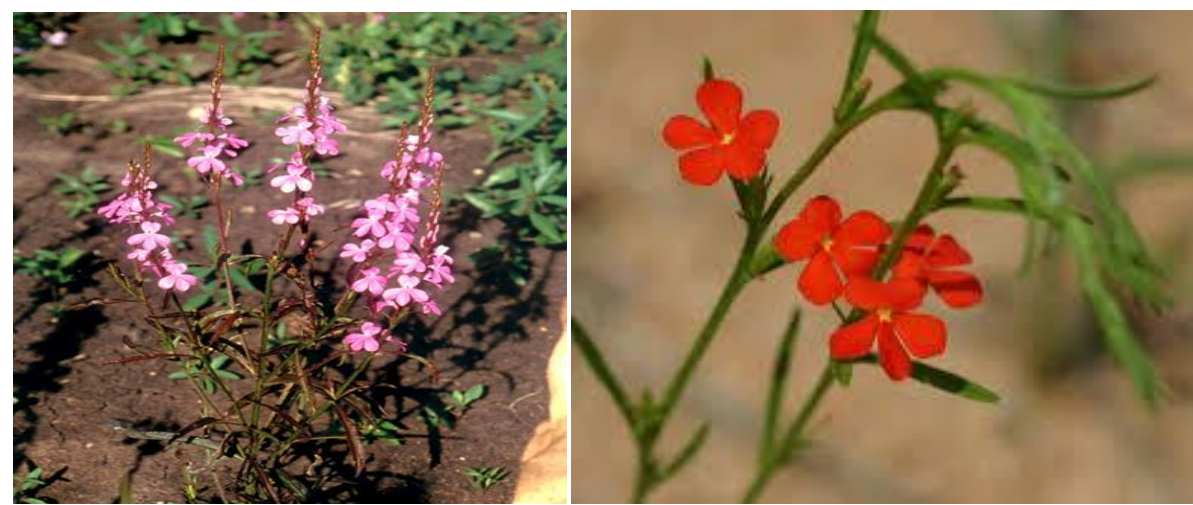

Figure2. Striga hermonthica and asiatica

Striga is an obligate hemi-parasitic weed which needs a host plant to complete its life cycle, but, having chlorophyll us leaves, it is not entirely dependent on its host for its metabolic requirements (Kuijt, 1969). Despite the green leaves, Striga continues to benefit from its host after emergence (Pageau et al., 1998). Striga damage is caused by parasitism, reduction in photosynthesis and increased partitioning of photosythates to the roots of host plants. It attaches itself to the host plant roots and in doing so, it weakens the crop plant by robbing carbon assimilates, water, nutrients and amino acids from its host (Pageau et al., 2003). Upon Striga infection abscisic acid levels in the crop increase while levels of cytokinins and giberellic acid decrease (Drennan and El Hiweris, 1979).

By changing this balance of plant growth regulators in the host, Striga negatively affects host photosynthesis (Press and Stewart, 1987; Gurney et al., 1995) and alters the biomass allocation of its host. More biomass is allocated to the roots at the expense of the stem (Graves et al., 1989). Furthermore, Striga reduces the water use efficiency (Gebremedhin et al., 2000) and strongly affects the water economy of the host plant through its high transpiration rates and making the crop most susceptible to drought.

\subsection{Origin and Domestication of Striga}

The genus Striga includes over 40 species, of which 11 species are considered parasitic on agricultural crops. Africa is thought to be the center of origin for Striga. The prevalence and extent of genetic diversity of a species in a particular geographic area, where more forms appear and specialized associations are observed, are often indicators of origin for plant species. The vast tropical savannah between the Semien mountains of Ethiopia and the Nubian hills of Sudan has the greatest biodiversity of sorghum and pearl millet, the two crops that Striga readily infests, as well as that of the parasite population itself. This area is recognized as the center of origin for sorghum and pearl millet and may also be the home of the two species of Striga affecting cereals, namely S. hermonthica, and S. asiatica.

The species that is specially adapted as a pest of legume crops, S. gesnerioides, may have originated in western Africa. Today, Striga is found in almost all regions of sub- Saharan Africa, except in areas where rainfall is too high or in high altitude areas where temperatures may be too low for 
development of the parasite, but is most severe in infertile, nutrient depleted soils with low organic matter content. S. hermonthica has the largest geographical distribution. With its obligate out-crossing behavior and its large plant stature, it is the species that causes the greatest crop damage. S. hermonthica is found in much of sub-Saharan African with particular prevalence in western, central, and eastern Africa, as well as parts of the south-western part of the Arabian Peninsula across the Red Sea. S. asiatica has its widest distribution in the eastern and southern Africa. It is also found in Asia, particularly in southern India, as well as the United States and Australia.

S. gesnerioides occurs in Africa, the Arabian Peninsula, the Indian subcontinent, and has also been introduced to the United States. This species causes its greatest economic damage on legume crops widely grown in western Africa, particularly cowpeas. Both S. gesnerioides and S. asiatica are selffertile resulting in apparent genetic variability observed as distinct morph types as well as parasitic specialization. They appear to be distinctly less variable than the obligately out-crossing S. hermonthica.

\subsection{Distribution of Striga and Infestation in Ethiopia}

In Ethiopia striga is major biotic constraint and serious threat of subsistence food production. The weed is endemic to the country according to earlier records (Rechard et al, 1982). About 12 striga species are believed to occur in the country; only seven have been registered so far. These are in order of importance striga hermonthica on sorghum, maize, millet and other cereal such as tef; Striga asiatica on sorghum and maize; Striga aspera on maize; Striga latericea on sugarcane; Striga gesnerioideson sweet potato; Striga for besii and Striga pinatifidaonwild vegetation.

According to Fasil and Parker striga hermonthica is the dominant species it is most sever in highly degraded areas of North, North Western and Eastern parts of the country such as Tigray, Wollo, Gonder, Gojjem, North Shea and Eastern Harerghe (figure 4).Scientist in Ethiopia think that striga is the bigger problem in the country compared to the other SSA countries because it is found everywhere.

\subsubsection{Preferred Habitat}

Striga generally prefer infertile soils in open grasslands and savannah in semi-arid tropical areas. Their seeds are well adapted to hot, dry conditions, remaining dormant until rain. While perhaps best suited to dry, tropical areas, S. asiatica has been recorded from a range of climate zones, including seasonally dry tropics and subtropics as well as warm temperate regions (generally where it is dry or at least seasonally dry). S. hermonthica and S. Gesnerioides also prefer hot, arid or semi-arid areas, but the latter has naturalized in Florida, which is subtropical and seasonally wet (Csurhes et al., 2013). The parasite is most problematic in agricultural systems characterized by short or non-existence of fallow period, depleted soil fertility and low input of fertilizers, pesticides, improved seeds and modern management practices (Oswald, 2005).

Csurhes et al. (2013) noted that to germinate, Striga seeds require temperatures between $25-35^{\circ} \mathrm{C}$. The optimum temperature for germination for S. hermonthica and S. asiatica is $35{ }^{\circ} \mathrm{C}$ (Parker and Riches, 1993). S. asiatica tolerates lower temperatures than many other Striga species and has flourished in temperate regions outside its native range. Its seeds remain viable even after periods of storage at $-7^{\circ} \mathrm{C}$. Plants reach maturity at a daily mean temperature of $22{ }^{\circ} \mathrm{C}$. Such environmental flexibility might enable this species to expand its geographic and host range. S. hermonthica tolerates a range of day/ night temperatures between $40 / 30{ }^{\circ} \mathrm{C}$ and $25 / 15^{\circ} \mathrm{C}$ (Mahmoud et al., 2013).

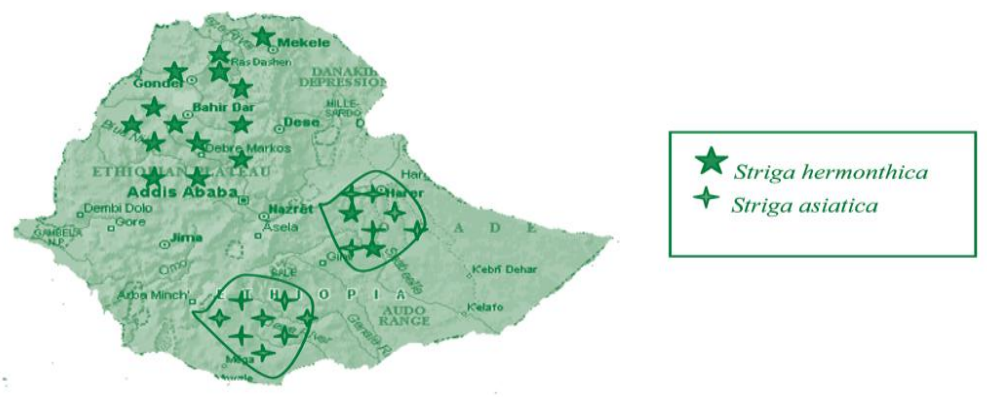

Figure3. Distribution of two major striga species in Ethipopia

(Sources: Fasil Reda) 
The witch weed infestation is high in parts of Africa including Ethiopia. Infestation by Striga could result in yield loss of few percentages and in some cases complete crop failure (Gurney et al., 2002; Rodenburg et al., 2005). Ejeta et al. (2002) indicated that in countries such as Ethiopia and Sudan, losses of $65-100 \%$ are common in heavily infested fields. In Ethiopia northern parts are specially majority of Tigrai and parts of Amhara, Eastern parts East Hararghe, SomaleWestern parts Gambela region are highly infested. At African level Ethiopia is assigned under heavily infested country.

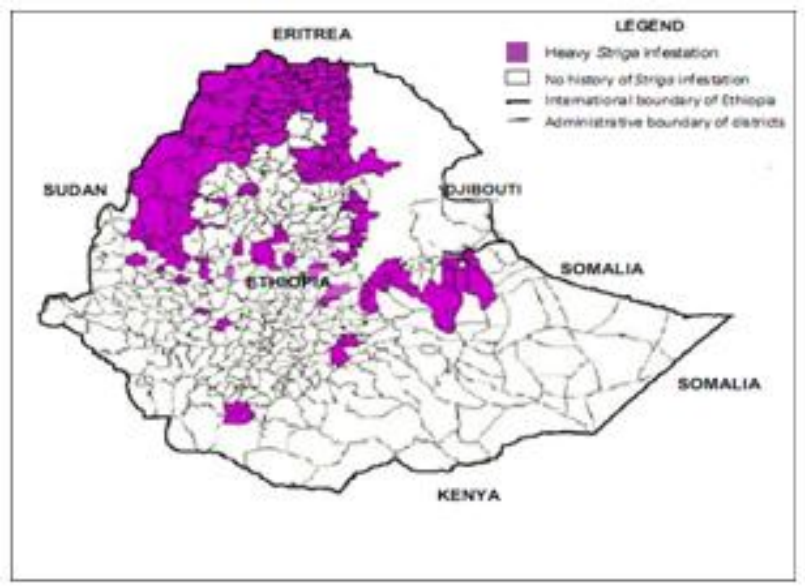

Figure4. Historically known areas with heavy Striga infestation in Ethiopia

Source: Tesso et al., 2007

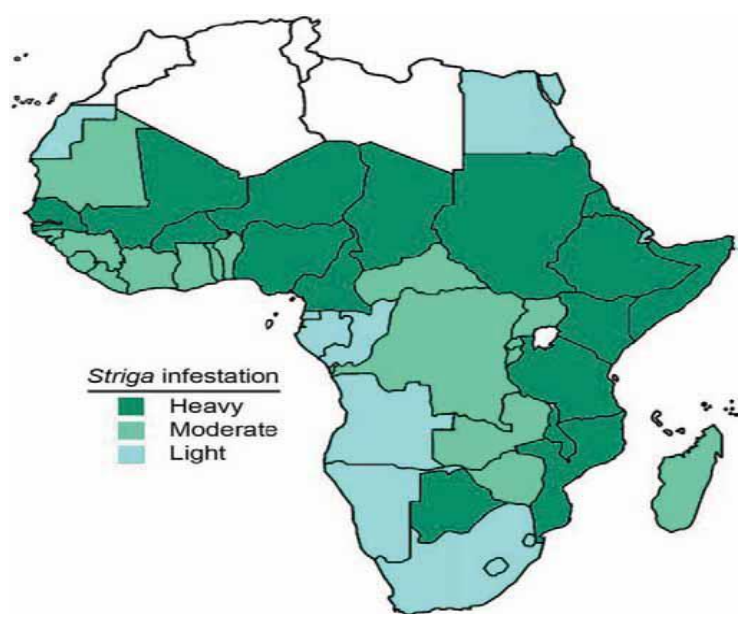

Figure5. Degree of Striga infestation in Africa.

Source: Integrating New Technologies for Striga Control, 2007

\subsection{Effect and Loss Due to Striga}

Yield losses caused by Striga are often significant and infestation by Striga usually results insubstantial yield reduction often surpassing $65 \%$ in heavily infested fields. As indicated by Haussmann et al. (2000) grain yield losses of up to $100 \%$ are possible on susceptible sorghum cultivars under high Striga infestation levels. Ejeta et al. (2002) indicated that in countries such as Ethiopia and Sudan, losses of $65-100 \%$ are common in heavily infested fields but total loss can occur when Striga attack is compounded by drought. In some areas, the attack is so severe that farmers cannot grow sorghum anymore; they have either abandoned their land or switched to other less important crops (Reda and Parker, 1994).

That parasitic weeds are significant constraints of crop production in much of Africa is widely recognized. However, hard data on the extent of spread, yield losses, impact on the economy and welfare of nations or households have not been available, except for the few reports that continue to be repeatedly cited. These estimates, rough as they are, have examined national and regional impact of parasitic weeds and have been useful, but they pose some limitations in extrapolating to continental impact. 
In general, average yield losses due to Striga are estimated at or above $50 \%$. The total area under severe to moderate Striga infestation had been estimated to range from 30 to 50 million hectares. Nevertheless, estimates on the extent of crop damage in a country or region in the African continent vary depending on prevalent cultural practices, the crop cultivar, and degree of infestation. Much spread has occurred since these early and rough estimates were made, but no new figures have emerged. The degree of Striga infestation is most severe in eastern Africa where invasion by the parasite is expanding at an alarming rate, often resulting in total loss of crops in any given crop season.

Table1. Degree of Striga infection on crops

\begin{tabular}{|c|c|c|c|c|c|c|c|}
\hline \multirow[b]{2}{*}{ Strigaspecies } & \multicolumn{7}{|c|}{ Crops } \\
\hline & Maize & Sorghum & Rice & Pearlillet & Finger millet & Cowpea & Sugarcane \\
\hline S. hermonthica & $\mathrm{xxx}$ & $\mathrm{xxx}$ & $\mathrm{xx}$ & $\mathrm{xxx}$ & $\mathrm{xxx}$ & - & $\mathrm{Xx}$ \\
\hline S. angustifolia & - & $\mathrm{xx}$ & - & - & - & - & $\mathrm{Xx}$ \\
\hline S. asiatica & $\mathrm{xxx}$ & $\mathrm{xxx}$ & $\mathrm{XX}$ & $\mathrm{xx}$ & $\mathrm{XX}$ & - & $\mathrm{X}$ \\
\hline S. forbesii & $\mathrm{X}$ & $\mathrm{x}$ & $\mathrm{X}$ & - & - & - & $\mathrm{X}$ \\
\hline S. aspera & $\mathrm{xx}$ & $\mathrm{x}$ & $\mathrm{xx}$ & - & $\mathrm{X}$ & - & $\mathrm{X}$ \\
\hline S. gesnerioides & - & - & - & - & - & $\mathrm{XXX}$ & - \\
\hline S. latericea & - & - & - & - & - & - & $\mathrm{X}$ \\
\hline S. pubiflora & - & - & - & - & - & - & $\mathrm{X}$ \\
\hline
\end{tabular}

Note: $x x x$-Serious infection, $x x$-Moderate infection, $x$-Less infection, No infection

Sources: Parker and Riches, 2011

\subsection{Sorghum Genetic Diversity and Potential in Ethiopia}

The genus Sorghum has five subgenus or sections: Eu-Sorghum, Chaetosorghum, Heterosorghum, Para-Sorghum, and Stiposorghum (Garber, 1950 cited by Upadhyaya et al., 2009), of which, EuSorghum contains all sorghum races and varieties, wild and weedy relatives (Doggett, 1988). Further, Harlan and de Wet (1972) recognized five basic races (bicolor, guinea, caudatum, kafir, and durra) and ten intermediate races (guinea-bicolor, guinea-caudatum, guinea-kafir, guinea durra, caudatumbicolor, kafir-bicolor, durra-bicolor, kafir-caudatum, kafir-durra, and durra-caudatum) that originated as a result of natural intercrossing among basic races, all recognizable on the basis of spikelet/panicle morphology, which can be linked back to their specific environments and the nomadic peoples that first cultivated them (Smith and Frederiksen, 2000). The race bicolor is widely distributed in Africa and Asia; guinea, predominant in West Africa; caudatum, throughout Central Africa; kafir, south of the equator in Africa; durra, in Ethiopia and India (Harlan and de Wet, 1972).

Kebede (1991) and Teshome et al. (1997) reported four races (bicolor, caudatum, durra and guinea) are found in Ethiopia. On the other study made in Eastern Ethiopia, Firew (2006) reported five basic races, the typical durra race is found in the lowlands; durra, durra-caudatum, and caudatum are found in the intermediate altitudes and bicolor-caudatum, guinea-caudatum, and bicolor races are found in the highlands.

The International Crops Research Institute for the Semi-Arid Tropics ( ICRISAT) with a global mandate for sorghum improvement research in the semi-arid tropics (SAT) owns one of the largest collections of global sorghum germplasm accessions in its gene bank (Kumar et al., 2011). It is a major repository of global germplasm collection with a total of 36,774 accessions from 90 countries including Ethiopia and the existing collections represent about $80 \%$ of the variability present in the crop (Reddy et al., 2008).

Ethiopia is also an important germplasm source for sorghum improvement program worldwide. Over 10,000 indigenous sorghum germplasm accessions were collected from different sorghum producing regions of the country and evaluated for some agronomic and taxonomic characteristics earlier by Ethiopian Sorghum Improvement Program and later by the Institute of Biodiversity Conservation.

In Ethiopia, sorghum is grown in 8 major agro ecologies and 20 sub agro ecologies that cover about $66 \%$ of the total land mass of the country (EARO, 2000). As diverse as the sorghum growing environments is the genetic variability observed in the crop in terms of grain color, quality, plant height, disease and pest resistance, adaptation to wide array of temperature and moisture regime 
(Gebeyehu et al., 2004). Such highly variable genetic resources are very useful for sorghum improvement program (Ayana and Bekele, 1998; Ayana et al., 2000; Abdi et al., 2002; Firew, 2006).

Therefore, plant genetic resources are invaluable input for sustaining and improving agricultural productivity. The collection and conservation of genetic diversity of important food crops like sorghum has been given significant focus due to concerns over loss of genetic resources (Firew, 2006). Moreover, only small fractions of the total available collection have been utilized by breeders.

Ethiopia is a center for genetic diversity for many domesticated crop plant species such as sorghum, barley, tef, chickpea and coffee, largely represented in the country by local landraces and wild types that are exceptionally adapted to adverse environmental conditions, genetically diverse forms. Much of this crop diversity is found in small fields of small scale farmers, have played a great role in the creation, maintenance and efficient utilization of resources (Worede et al., 2000; Abe, 2010).

Being Sorghum is an indigenous crop of Ethiopia, tremendous amount of variability exists in the country (Asfaw, 2007); Ethiopia serves as the global reservoir for sources of favorable genes of various crops to which it is the Vavilonian center of origin and diversity including sorghum. Ethiopian farmers grow mixed sorghum landraces of diverse forms in their fields for various local purposes. Ethiopian sorghum germplasm has been highly contributing to the global agriculture (Asfaw, 2014) as Ethiopia ranks first among countries that have contributed germplasm collections to the world collections of sorghum at the International Crop Research Institute for Semi-Arid Tropics (ICRISAT) (Prasad Rao et al., 1989), indicating that Ethiopia is a rich source of sorghum landraces.

\subsection{Striga Management Options}

\subsubsection{Soil Fertility}

Striga is more favor in less fertile soil, a system that would improve soil fertility to increase yield as well as reduce Striga infestation, will be also of double advantage. Good soil management practices involving the use of crop residues and organic manure have been effective control measure against Striga (Vogt W, 1991).

Striga infestation decreased with increasing organic matter of the soil and that organic matter content seemed to be the most important factor which preserved the soil fertility. Since soil microbial biomass flourishes better in a medium rich in organic matter, organic or inorganic soil amendments may increase soil suppressiveness to Striga spp. and also improve soil conditions to increase yield of subsequent cereals (Berhane, 2016).

\subsubsection{Inter Cropping}

Some studies indicate that intercropping with cowpeas between the rows of maize significantly reduced Striga numbers when compared to within the maize rows (Odhiambo GD 1993). Moreover, finger millet intercropped with green leaf desmodium reduced Striga hermonthica counts in the intercrops than in the monocrops (Midega, 2010). According to (Fasil R, 2005) also reported related findings on sorghum cowpea intercropping where Striga emergence was lower under intercrops than sole crops.

Generally, various studies have shown that intercropping cereals, mainly with legumes such as cowpea, peanut and green gram can reduce the number of Striga plants (Carsky RJ, 2000). Potentially they might be acting as traps crops and interfere with Striga germination and development (Parker C and Riches CR.1993).

\subsubsection{Biological Control Methods}

Biological control is particularly attractive in suppressing root parasitic weeds in annual crops because, of the intimate physiological relationship with their host plants makes it difficult to apply conventional weed control measures. Currently, biological control using microbes is becoming a critical component of integrated management of Striga, given that the bio-control agents are usually host specific, highly aggressive, easy to mass produce and diverse in terms of the number of isolates (Ciotola et al., 1996). Biological control methods are also relatively economical, may be selfperpetuating and are usually free from negative residual effects. Management of Striga through biocontrol agents is also much safer and less polluting to the environment than the use of chemical pesticides (Abbasher et al., 1998). 


\subsubsection{Host Plant Resistance}

Striga resistance is the ability of the host root to stimulate Striga germination but at the same time prevent attachment of the seedlings to its roots or to kill the seedlings when attached. The use of resistant crop cultivars is the most economically feasible and environmentally friendly means of Striga control. In East Africa, the most promising new approach to Striga control is the use of resistant cultivars for instance sorghum. Striga resistant cultivars have -been bred in a number of crops. However, cultivars with immunity to Striga have not been found in all host crops. The host/parasite relationship is governed by a series of steps involving stimulation of germination, haustorium initiation, penetration of the host root, connection to the host xylem and concurrent growth (Butler LG.1993).

Many cereals are found to be naturally resistant to Striga e.g.; rice, sorghum and some genotypes of maize. A resistant plant stimulates germination of Striga but it does not allow it to attach to the root. On the other hand, a Striga tolerant genotype stimulates germination and supports as many Striga plants as the sensitive genotype but produces more grain and shows fewer damage symptoms (Kim, 1994).Study in Striga infested areas revealed cultivation with resistant crops results in fewer Striga plants and higher crop yield than anon-resistant genotype of the cultivated plant would do (Rodenburg J, 2014).

\subsection{Achievement to Control Striga}

In Ethiopia several striga resistance varieties were developed. The striga-resistant cultivars such as Gobiye, Abshir and Birhan are released by the Sirinka Research Center for striga-infected fields, in the Kobo and Sirinka areas show about a three-fold increase in yield (25-34 q/ha) as compared to control sites. Increased use of the new varieties could produce vastly improved yields in the Kobo area alone. The ISM strategy included an improved striga-resistant cultivar, methods of fertilizer application, and proper crop management practices.

\section{CONCLUSION}

Witch weeds (Striga spp.), endemic parasitic weeds of sub-Saharan Africa are steadily increasing their geographic domain and level of infestation, and thereby greatly reducing crop yield. The Striga species are among the most specialized of all root-parasitic plant parasites.

In Ethiopia striga is major biotic constraint and serious threat of subsistence food production. Striga hermonthica is the dominant species and it is most sever in highly degraded areas of North, North Western and Eastern parts of the country such as Tigray, Wollo, Gonder, Gojjem, North Shewa and Eastern Harerghe. Striga is, therefore, fast becoming a pandemic of serious proportions in the country because of its vast geographic spread and its economic impact on millions.

Striga remains the major constraints not only to sorghum but also to many other cereals. Annual sorghum loss attributed to striga in SSA is estimated to $22-27 \%$ and $25 \%$ in Ethiopia. The annual loss of all cereals due to striga is $\$ 7$ billion in SSA and the share of Ethiopia is $\$ 75$ million. Sorghum is an indigenous crop of Ethiopia, tremendous amount of variability exists in the country; Ethiopia serves as the global reservoir for sources of favorable genes of various crops.

Ethiopian sorghum germplasm has been highly contributing to the global agriculture as Ethiopia ranks first among countries that have contributed germplasm collections to the world collections of sorghum at the International Crop Research Institute for Semi-Arid Tropics (ICRISAT), indicating that Ethiopia is a rich source of sorghum landraces. There is potential to develop striga resistance sorghum varieties in the country.

\section{REFERENCES}

[1] Ayana, A and Bekele, E 1998, Geographical patterns of morphological variation in sorghum [(Sorghum bicolor (L) Moench)] germplasm from Ethiopia and Eritrea: qualitative characters. Hereditas, 129: 195205

[2] Ayongwaa, G.C., Stompha, T.J. Hoeversc, R. Ngoumoud, T.N. Kuypere, T.W. 2010.Strigainfestation in northern Cameroon: Magnitude, dynamics and implications for management. Wageningen Journal of Life Sciences,

[3] A.T. Obilana and K.V. Ramaiah, Striga (Witch weeds) in Sorghum and Millet: Knowledge and Future Research Needs. 
[4] Badu-Apraku, B. and Akin wale, R. O. 2011 Cultivar evaluation and trait analysis of tropical early maturing maize under Striga infested and Striga free environments. Field Crops Research,

[5] Berhane Sibhatu Review on Striga Weed Management,2016 Department of Agronomy, Ethiopian Institute of Agricultural Research, Mehoni Agricultural Research Center

[6] Doggett, H. 1988. Sorghum 2nd Edition Tropical Agriculture, Series Longman Scientific \& Technical, Essex, England

[7] Ejeta, G. 2007. Breeding for Striga resistance in sorghum: exploitation of an intricate host parasite Biology Crop Science 47:216-227

[8] Ejeta, G., 2007. The Striga scourge in Africa: a growing pandemic. pp. 3 - 16. In: Ejeta, G.,

[9] Gressel, J. (Eds.), Integrating New Technologies for Striga Control - towards Ending the Witch Hunt. World Scientific, Singapore

[10] Ejeta, G., Babiker, A.G.T. and Butler, L. 2002. New approaches to the control of Striga, a training workshop on Striga resistance. Melkassa, May 14-17, (2002). Nazareth, Ethiopia.

[11] Fasil, R. and Parker, C. 1994. Distribution and importance of Striga and related parasitic weeds in Ethiopia.

[12] Evans A. Atera, Kazuyuki Itoh and John C. Onyango Evaluation of ecologies and severity of Striga weed on rice in sub-Saharan Africa, 2011.

[13] FAOSTAT 2014, Database of agricultural production FAO Statistical Databases (FAOSTAT) http://faostat.fao.org/default.aspx

[14] Hayelom Berhe Teka, Advanced Striga control, African journal of plant sciences, 2014

[15] Haussmann, B.I.G., Hess, D.E. Weiz, H.G. and Geiger, H.H. 2000. Improved methodologies for Breeding, Striga resistant sorghums, Field Crops Research,

[16] MESFIN ABATE, 2016 Assessment of Striga infestation and Evaluation of sorghum landraces for Resistance/Tolerance to [Striga hermonthica (Del.) Benth] in North-Western Ethiopia.

[17] Mesfin, A., Firew, M. Temam, H. Wondimu, B. and Fasil, R. 2014. Assessment of genetic diversity in sorghum [(Sorghum bicolor (L.)Moench)] for reaction to Striga hermonthica (Del.) Benth. Australian Journal of Crop Science

[18] Rebeka Gebretsadik Teshome, 2014 Integrating Sorghum [Sorghum bicolor (L.) Moench] Breeding and Biological Control Using Fusarium oxysporum Against Striga hermonthica in Ethiopia

[19] Rebka, G., Shimelis, H. Laing, M.D. Tongoona, P. and Mandefro, N. 2014. A diagnostic appraisal of sorghum farming system and breeding priorities in Striga infested agro ecologies of Ethiopia. Agricultural System,

[20] Temam, H. 2006. Distribution of two Striga specious and their relative impact on local and resistant sorghum cultivars in east Ethiopia. Tropical Science

[21] Parker, C, 1991 Protection of crops against parasitic weeds Crop Protection

[22] Yoneyama, K., Ayman, A.A. Xiaonan, X. Yoneyama, K. and Yasutomo, T. 2010. Strigolactones as germination stimulants for root parasitic plants. Plant cell and Physiology.

Citation: Temesgen Teressa, (2019). "Review on Striga Distribution, Infestation and Genetic Potential in Ethiopian Sorghum (Sorghum Bicolor (L.) Moench)" International Journal of Research Studies in Agricultural Sciences (IJRSAS), 5(2), pp.23-31, http://dx.doi.org/10.20431/2454-6224.0502004

Copyright: (c) 2019 Authors. This is an open-access article distributed under the terms of the Creative Commons Attribution License, which permits unrestricted use, distribution, and reproduction in any medium, provided the original author and source are credited. 